\title{
Laboratory scale evaluation of Effective Microorganisms in the control of odor of organic waste from a market in the city of Riobamba, Ecuador
}

Cristina Calderón-Tapia ${ }^{1}$, Abigail Montero-Calderón², María Núñez-Morenoํㅡㄹ Esteban Pazmiño-Arias² DOI. 10.21931/RB/2020.05.01.6

Abstract: Inadequate waste management and poor storage conditions are a problem that still affects the population and environment. In the city of Riobamba (Chimborazo, Ecuador) some people feel affected by odor pollution generated by the accumulation of waste in landfills near to markets, corners, and public places. For minimizing this problem, the present work analyzed the potential odor reduction of organic waste from a market located in Riobamba, using Effective Microorganisms: Lactobacillus plantarum, Rhodopseudomonas palustris, Streptomyces albus, and Aspergillus oryzae. Four combinations of cocktails were formed subsequent to evaluating the antagonism of microbial strains. The odor sensory evaluation was carried out by 40 people using the American Society of Heating, Refrigeration and Air Conditioning Engineers odor scale, biochemical oxygen demand, chemical oxygen demand, temperature, $\mathrm{pH}$, conductivity, turbidity, and color were measured in the treatment which reached imperceptible odor intensity. In this way, the cocktail formed by the four strains of Effective Microorganisms presents a reduction in the values of the physicochemical parameters of the leachate compared to the sample without the microorganisms, and furthermore, that cocktail controls bad smell produced by the decomposition of organic matter. Therefore, the application of Effective Microorganism opens up a possibility for the treatment of organic waste within local garbage collection stations.

KeyWords: Odor, decomposition, control, Effective Microorganisms.

\section{Introduction}

Solid waste is the biggest problem of environmental impact worldwide; they affect the soil and air quality by the gases produced at their decomposition. Additionally, they transform water when they are deposited into it or dragged by rain. Organic waste resulting from animal, agricultural, and industrial production is the primary source of pollution in several countries ${ }^{1}$.

In 2014, approximately 11203.24 tons of solid waste were collected daily in Ecuador; of that, 62\% was organic waste, $25 \%$ was a recyclable inorganic waste, and $13 \%$ was non-reusable hazardous waste ${ }^{2,3}$. In 2010, an average of 150 tons of solid waste per day was generated in the city of Riobamba (Chimborazo, Ecuador) by 225.74 habitants ${ }^{4}$. The biggest problem in Riobamba is odor pollution, due to the accumulation of waste in landfills located in markets, corners, and public places.

The decomposition of organic waste is a severe problem due to the large amount produced, also, air pollution due to bad odors has been increasing in recent years. In Spain for example, $25 \%$ of the population feels affected by this problem: in Ecuador, $26.76 \%$ of the population indicates having issues due to inadequate environmental odors ${ }^{5}$.

Some gases are generated as a result of waste rot: acetic acid, acetaldehyde, ammonia, amines, mercaptans, phenol, toluene, sulfuric acid, and other sulfur compounds ${ }^{6}$.

Additionally, the incorrect way of waste storage can generate the production of pathogens, which present a high risk to the health of the population, and mainly to people who handle the waste for final disposal ${ }^{7}$.

Effective Microorganisms (EM) are cultures of mixed organisms that degrade organic matter and allow its use for plants, improve soil characteristics and conditions for agriculture. The EM was formulated as a microbial cocktail using: photosynthetic bacteria, lactic acid bacteria, yeasts, fungi, and actinomycetes. In the process of rotting organic matter, the EM produces organic acids that are not usually in the soil, such as lactic acid, acetic acid, amino acids, malic acid, and vitamins that could be absorbed by plants ${ }^{8}$.

This research aimed to formulate a microbial cocktail that reduces odors caused by the decomposition of organic waste. Four strains of microorganisms were chosen to obtain an EM consortium: Lactobacillus plantarum, Rhodopseudomona palustris, Streptomyces albus, and Aspergillus oryzae to check the ability of the microbial consortium to reduce the substances that produce bad odors from the waste by removing pathogenic microorganisms through competitive exclusion.

\section{Materials and methods}

This study was carried out in the Molecular Biology-Genetics and Microbiology laboratory at Science Faculty, Escuela Superior Politécnica de Chimborazo (ESPOCH), Ecuador. The culture collection is belonging to Plantsphere Laboratories, Quito, Ecuador (Table 1).

\section{Antagonism test}

A confrontation was made between the four microbial strains in Petri dishes with PDA medium at $28^{\circ} \mathrm{C}$ for seven days. The microbial suspensions were prepared in concentrations of $1 \times 10^{4} \mathrm{CFU} \mathrm{mL} \mathrm{m}^{-1}$, in saline solution for L. plantarum and $R$. palustris, and tween $800.1 \%$ for S. albus. Then $5 \mathrm{~mm}$ diameter discs of $A$. oryzae were taken, using sterile punches ${ }^{9}$. Three essays of the antagonistic effect and three controls were performed with the fungus.

The inhibition rate was determined by I $=[(\mathrm{C}-\mathrm{T}) / \mathrm{C}] \times 100$. Where, $\mathrm{C}$ is the radius of the mycelium of the control, $\mathrm{T}$ is the radius of the mycelium.

\footnotetext{
${ }^{1}$ Faculty of Science professor. Escuela Superior Politécnica de Chimborazo (ESPOCH).
}

${ }^{2}$ Researcher Yachay Tech University. 


\begin{tabular}{|c|c|c|c|}
\hline Microorganisms & Code & Treatment & Provenance \\
\hline $\begin{array}{l}\text { Lactobacillus } \\
\text { plantarum }\end{array}$ & PSL 40215 & $\begin{array}{l}\text { Enriched in TSB } \\
\text { broth, seeded in } \\
\text { MRS medium, } 24 \\
\text { hours, } 30^{\circ} \mathrm{C}\end{array}$ & Probiotics \\
\hline $\begin{array}{l}\text { Rhodopseudomonas } \\
\text { palustris }\end{array}$ & PSL 40460 & $\begin{array}{l}\text { Seeded in PDA } \\
\text { medium, } 5 \text { days, } \\
28^{\circ} \mathrm{C}\end{array}$ & $\begin{array}{l}\text { Organic substrates } \\
\text { and dairy products }\end{array}$ \\
\hline Streptomyces albus & PSL 40123 & $\begin{array}{l}\text { Seeded in } \mathrm{PDA} \\
\text { medium, } 7 \text { days, } \\
28^{\circ} \mathrm{C}\end{array}$ & Organic material \\
\hline Aspergillus oryzae & PSL 50127 & $\begin{array}{l}\text { Seeded in PDA } \\
\text { medium, } 5 \text { days, } \\
28^{\circ} \mathrm{C}\end{array}$ & Rice seed \\
\hline
\end{tabular}

Table 1. Summary of the methods for microbial strains activation.

\section{Treatment design}

Four treatments (T1 to T4) and control treatment (T5) was performed with three repetitions each, with concentrations described in Table $2^{10}$.

To determine a concentration of microorganism to work, the spore counts of $A$. oryzae and $S$. albus strains was performed in triplicate using a Neubauer chamber. Once the required concentration was found, the inoculums were stored at $5^{\circ} \mathrm{C}$ until the preparation of the EM cocktails.

Additionally, the inoculum of L. plantarum and R. palustris was suspended into $10 \mathrm{~mL}$ of saline solution, homogenized in a vortex for 5 minutes, and successive dilutions were made until $10^{-5}$. To define a concentration, each dilution was counted by triplicate in a cell counting chamber ${ }^{11}$. treatment if the smell was homogeneous or if it was in advanced decomposition. The scale used for the analysis of the tests is shown in Table 3 and is proposed by the American Society of Heating Refrigerating and Air Conditioning Engineers (ASHRAE). Additionally, some parameters as temperature, $\mathrm{pH}$ and conductivity were measured for each treatment into experimental devices ${ }^{15}$.

\begin{tabular}{|c|c|c|}
\hline VALUE & CORRESPONDS TO & Table 3. Relative \\
\hline 0 & No odor & cale. \\
\hline 1 & Slight & \\
\hline 2 & Moderate & \\
\hline 3 & Strong & \\
\hline
\end{tabular}

\begin{tabular}{|cllll|}
\multicolumn{1}{c}{ Strains } & $\begin{array}{l}\text { R.palustris } \\
\text { CFU mL }\end{array}$ & $\begin{array}{l}\text { L. plantarum } \\
\text { CFU mL }\end{array}$ & $\begin{array}{l}\text { A. oryzae } \\
\text { spores } \mathrm{mL}^{-1}\end{array}$ & $\begin{array}{l}\text { S. albus } \\
\text { spores } \mathrm{mL}^{-1}\end{array}$ \\
$\begin{array}{c}\text { Treatment } \\
\text { Treatment 1 (T1) }\end{array}$ & $1 \times 10^{4}$ & $1 \times 10^{4}$ & $1 \times 10^{4}$ & $1 \times 10^{4}$ \\
\hline Treatment 2 (T2) & $1 \times 10^{6}$ & $1 \times 10^{6}$ & $1 \times 10^{6}$ & $1 \times 10^{4}$ \\
\hline Treatment 3 (T3) & $1 \times 10^{6}$ & $1 \times 10^{6}$ & $1 \times 10^{4}$ & $1 \times 10^{6}$ \\
\hline Treatment 4 (T4) & $1 \times 10^{6}$ & $1 \times 10^{6}$ & $1 \times 10^{6}$ & $1 \times 10^{6}$ \\
\hline Control (T5) & - & - & - & - \\
\hline
\end{tabular}

Table 2. Treatment design.

\section{Treatment Formulation}

The cocktails were prepared with: 90\% distilled water, $5 \%$ sterile molasses, and $5 \%$ of microbial inoculums $(1.25 \%$ of each $\mathrm{EM}$ inoculum); they were incubated at $28^{\circ} \mathrm{C}$ for 24 hours. For each treatment, the ratio of cocktail to organic waste was 1:1000. The biomass used as a substrate was obtained from the organic waste of markets from Riobamba. The substrate was chopped for obtaining a homogeneous mixture of $200 \mathrm{Kg} \mathrm{m}^{-3}$.

The presence of the microbial strains was checked, before and after the assays, by observation under the microscope: fungal staining using lactophenol blue dye $\mathrm{e}^{12}$ and the Gram staining technique was used for bacteria ${ }^{13}$.

\section{Odoriferous evaluation of cocktails}

A group of 40 heterogeneous people from 19 to 23 years old was selected. An eight days assay was performed ${ }^{14}$. The microbial cocktails were scattered on biomass on days: one, three, and six; and the odor evaluation was performed on days: one, three, six and eight. On day one, the organic waste was placed into experimental devices; the panel checked in each

\section{Leachate Analysis}

The leachates from the treatment with the highest efficiency on odoriferous evaluation and the control treatment were collected for determining: biochemical oxygen demand $\left(\mathrm{BOD}_{5}\right)$, chemical oxygen demand (COD), turbidity, color, temperature, $\mathrm{pH}$, and conductivity (Table 4). These analyses were performed in the Water Quality laboratory at Science Faculty, ESPOCH, Ecuador.

\section{Results and Discussion}

\section{Antagonistic activity}

The inhibition percentage associated with: L. plantarum, R. palustris, S. albus, and A. oryzae, ranged from $4 \%$ to $7.8 \%$. The low antagonistic degree of $A$. oryzae, equal to 1 , suggests that the fungus can invade $1 / 4$ of the surface of other microorganisms without damaging it. Additionally, the results show no formation of inhibition halos among the four microbial cul- 


\begin{tabular}{|ll|}
\hline Parameters & Methods and references \\
\hline BOD 5 & Digester Hach BODTrak ${ }^{\mathrm{TM}} 11$ for 5 days $^{16}$. \\
\hline COD & Volumetric method using a distillation equipment $^{17}$. \\
\hline Turbidity & $\begin{array}{l}\text { Hach RATIO XR Turbidimeter in a scale of } 1-2000 \mathrm{NTU} \\
\text { units }^{18} .\end{array}$ \\
\hline Color & $\begin{array}{l}\text { DR 2800 photometer at a wavelength of } 465 \mathrm{~nm} \text { in } \\
\text { platinum cobalt units (PCU) }\end{array}$ \\
\hline $\begin{array}{l}\text { Temperature, } \\
\text { conductivity } \text { and } \boldsymbol{p H}\end{array}$ & Consort $^{\mathrm{TM}}$ C562 multiparameter equipment ${ }^{15}$. \\
\hline
\end{tabular}

Table 4. Methods for monitoring leachate.

tures, so its use as a single consortium of microorganisms is recommended due to the symbiotic effect presented. Therefore fungi, actinomycetes, and bacteria can co-exist in a mixed culture $^{8}$; and they can be included in a biological treatment system for odor abatement ${ }^{20}$.

\section{Evaluation of the growth of the culture in the microbial consortium}

The four microbial cultures, which formed the initially mixed consortium, were remained after the treatments (Figure 1). Despite the notorious presence of $A$. oryzae, the growth of $R$. palustris, L. plantarum, and S. albus, was not inhibited.

The efficiency of a biological treatment system for odour reduction depends on its heterotrophic microbial consortium ${ }^{20}$. Lactobacillus plantarum, Streptomyces albus, and Aspergillus oryzae are heterotrophic microorganisms while Rhodopseudomonas palustris has a versatile metabolism; for that reason, when they were placed into organic waste and molasses as substrate, they had nutrients necessary for gain energy ${ }^{21}$ and growing after the treatments.

\section{Odor analysis}

The application of EM consortium had a significant effect $(p<0.05)$ on the differentiation of odor levels from organic waste, in fact, the panel perceived odor variations during the period of treatment until day eight. The use of pure cultures in biological treatment system for odor reduction in air, like they used in the mixed consortium for T1 to T4, ensures the early action against the potential pathogens that cause possible emissions of odour ${ }^{22}$; likewise, Fan, et $a^{2}{ }^{23}$, determined the reduction of time for elimination of pungent odor coming from the decomposition of organic matter on home scale organic waste composting, so the unpleasant smells of compost with EM varied to earthy smell on week five compared to control treatment (without EM) which generated earthy smell on week seven.

According to the sensory procedure performed ${ }^{14}$, T4 can be considered as an effective way to odor control of organic waste. The parameter "Strong odor" was: $25 \%, \mathrm{~T} 1 ; 17.5 \%$, T2 2.5\%, T3; and 0\%, T4; as shown in Figure 2. The threshold level of olfactory identification for some malodorous compounds is: 42 ppm, acetone; 17 ppm, ammonia, and 0.00041 ppm, hydrogen sulphide ${ }^{21}$. In this way, T4 could have eliminated the perception for unpleasant smell compared to control T5 which kept the parameter "Strong odor" on 80\% of the panel.

By comparison, the T4 contained the highest concentration of EM: $-10^{6} \mathrm{CFU} \mathrm{mL} \mathrm{m}^{-1}$ of L. plantarum and R. palustris, and

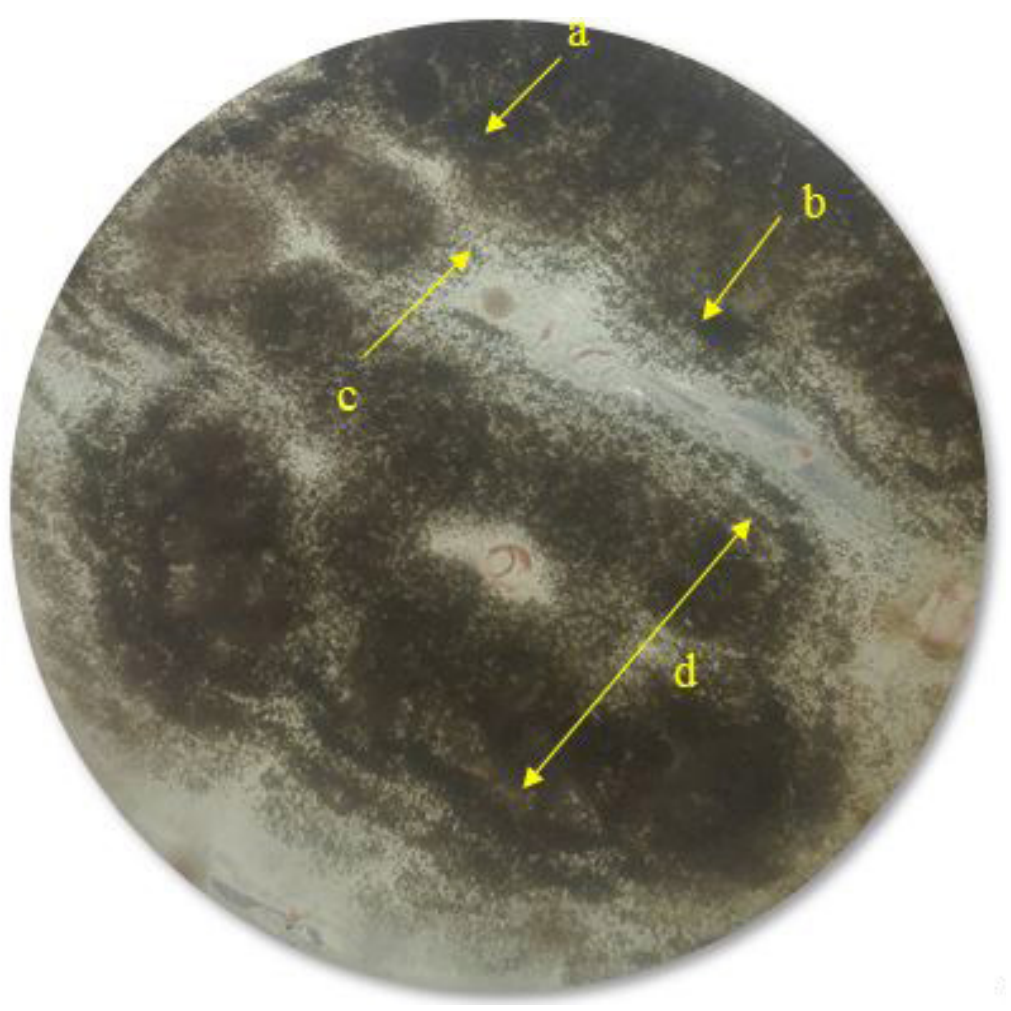

Figure 1. The consortium of microorganism: a) S. albus; b) L. plantarum; c) R. palustris; and d) A. oryzae. 


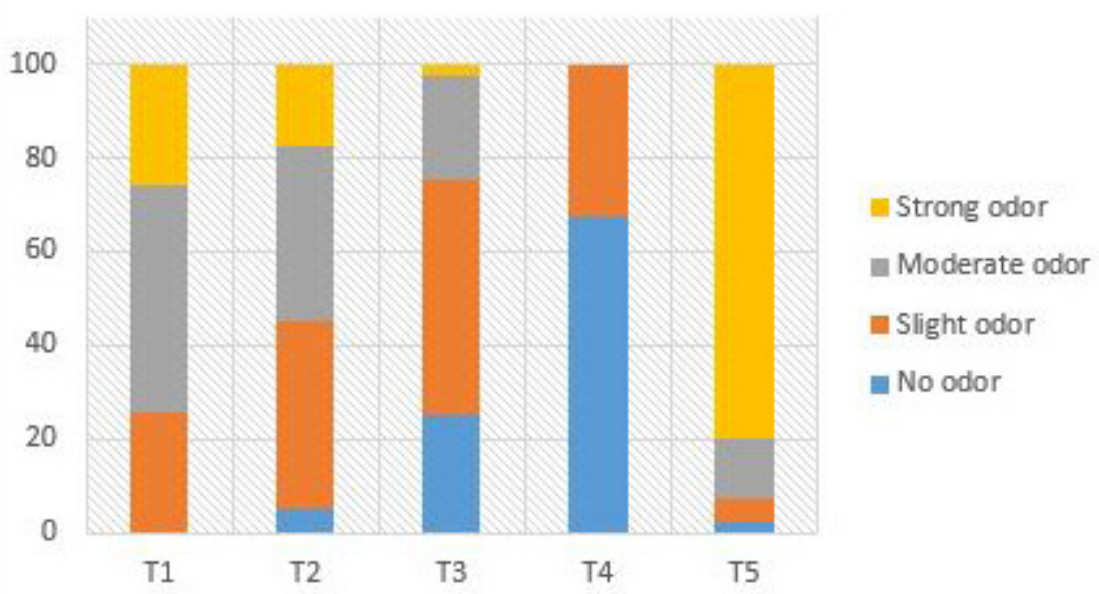

Figure 2. Odor levels by treatments with capable microorganisms (T1 to T4) and control without EM (T5).

$\sim 10^{6}$ spores $\mathrm{mL}^{-1}$ of S. albus and A. oryzae. Namasivayam and Kirithiga ${ }^{24}$ verified that native microorganism increased when EM consortium also increased, they used high concentrations of compost with EM $\left(12.1 \times 10^{6} \mathrm{CFU} \mathrm{g}^{-1}\right.$ of bacteria, $21.3 \times 10^{5}$ $\mathrm{CFU} \mathrm{g} \mathrm{g}^{-1}$ of actinomycetes, and $15.1 \times 10^{4} \mathrm{CFU} \mathrm{g}^{-1}$ of yeast and mold) for improving the soil nitrogen, phosphorus, and potassium levels.

\section{Effect of temperature and $\mathrm{pH}$}

The temperature had a gradual increase in all treatments (Figure 3), but the treatment without EM presented the lowest temperature $\left(23^{\circ} \mathrm{C}\right)$ at the end of the assay.

Changes in the temperature of the composting of organic wastes are closely related to microbial activity ${ }^{25}$; in this way, each increase of $10^{\circ} \mathrm{C}$ in the medium, is directly related to the microbial metabolic rate.

The highest temperature $\left(33^{\circ} \mathrm{C}\right)$ was reached at $\mathrm{T} 4$ on day 6. This behavior is similar to the presented by Song, et al. ${ }^{25}$, for the decomposition of organic waste, where a higher temperature was observed in the treatment with a microbial consortium instead of those without microbial inoculation.

On the other hand, the tests with EM had a pH equal to 6 on day 8 , while the maximum $\mathrm{pH}$ reached by the control treatment was balanced to 5 at the same time (Figure 4). The $\mathrm{pH}$ range suggested ${ }^{26}$ to carry out an appropriate degradation of organic matter with EM consortium is between 6 to 8.5; considering that in the initial phase of decomposition, the $\mathrm{pH}$ decreases during the first days; then it has a gradual increase until reaching values of 8.16 (at day 15) and 7.90 (at day 30).

The variation in $\mathrm{pH}$ can be related to the production of odors since acidification, neutralization, and alkalization of $\mathrm{pH}$ in composting processes are closely related to microbial activity through the release of ammonia and the conversion of organic acids into $\mathrm{CO}_{2}{ }^{25}$. Likewise, Miller, Macauley and Harper ${ }^{27}$, identified that a pH between 8 to 9 leads to the loss of nitrogen through the volatilization of ammonia, which is a compound identified as causing the bad smell in compost.

\section{Leachate analysis}

The values of $\mathrm{BOD}_{5}, \mathrm{COD}$, turbidity, and conductivity obtained for T4 against T5, were as shown in Table 5. In leachates generated from vegetable waste in composting processes in laboratory ${ }^{28}, \mathrm{COD}$ concentration varies between ranges from 18 to $68 \mathrm{~g} \mathrm{~L}^{-1}$, and for BOD5 between 10 and $46 \mathrm{~g} \mathrm{~L}^{-1}$; in this way, the COD values obtained for the leachates of T4 and T5 are within the typical range, while the BOD5 is below the lower limit.

In order to assess the level of contamination caused by

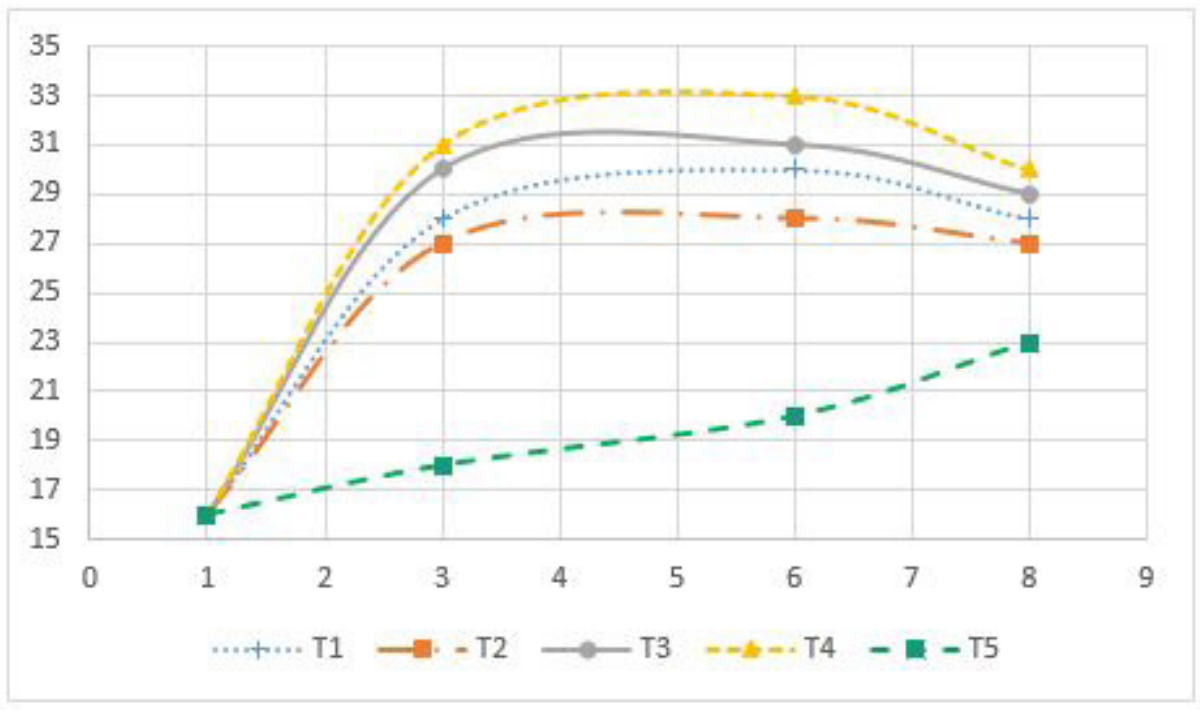

Figure 3. Temperature variations $\left({ }^{\circ} \mathrm{C}\right)$ for treatments with EM (T1 to T4) and control without EM (T5). 


\section{8

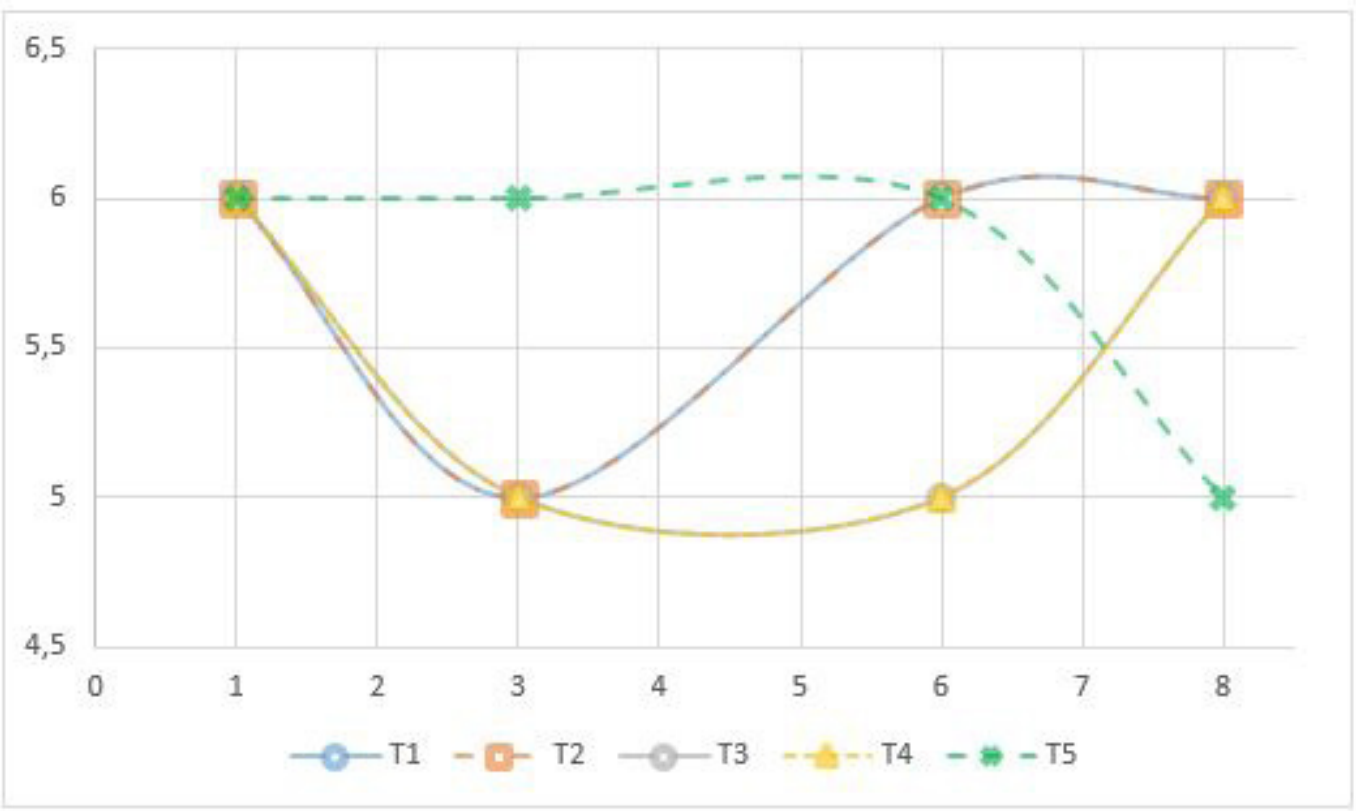

Figure 4. pH variations for treatments with EM (T1 to T4) and control without EM (T5).

organic matter, it is necessary to calculate the ratio of BOD/ COD to elucidate the biodegradability of the leachate ${ }^{28}$. In this sense, the leachate generated by the treatment with EM is moderately biodegradable (ratio T4 BOD/COD $=0.25$ ) compared to the treatment without inoculated microbial consortium, which has leaching with low biodegradability (ratio T5 BOD/ $\mathrm{COD}=0.16)$.

For the conductivity, the values of T4 and T5 (from 1.42 to $82.6 \mathrm{mS} \mathrm{cm}^{-1}$ ) are adjusted to the typical range for leachates of degradation processes from vegetable waste obtained in the laboratory ${ }^{28}$. Besides, T4 showed a $30 \%$ reduction in color units (232.34 PCU) compared to the treatment without the application of EM.

\begin{tabular}{|lcc|}
\hline Parameters & $\mathrm{T} 4$ & $\mathrm{~T}$ \\
\hline $\mathrm{BOD}_{5}\left(\mathrm{~g} \mathrm{~L}^{-1}\right)$ & 7.63 & 8.34 \\
\hline $\mathrm{COD}\left(\mathrm{g} \mathrm{L}^{-1}\right)$ & 30.67 & 53.33 \\
\hline Turbidity $(\mathrm{NTU})$ & 4547 & 8300 \\
\hline Conductivity $\left(\mathrm{mS} \mathrm{cm}^{-1}\right)$ & 1.82 & 3.75 \\
\hline
\end{tabular}

Table 5. Analysis of organic waste leached from T4 (with EM) and T5 (control).

\section{Conclusions}

The application of the microbial consortium formed by: Lactobacillus plantarum, Rhodopseudomonas palustris, Streptomyces albus, and Aspergillus oryzae had reduced odors produced by the decomposition of residues from a market of Riobamba, Ecuador. The present study was conducted only on organic wastes (legumes peel, vegetables and fruit leaves); for that reason, it should be considered as a preliminary study for the control of odors from another kind of waste. The

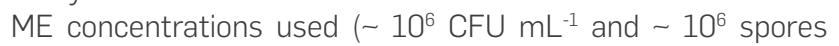
$\mathrm{mL}^{-1}$ ) achieved a reduction in the perception of strong odor according to the panel. The species of ME used in the microbial consortium were observed at the beginning and at the end of the treatments, which proves their symbiotic action within the biological deodorization treatment system. During the treatments, the measurement of $\mathrm{pH}$ and temperature was necessary for its use as operating parameters that guarantee the biological activity of the microorganisms.
Finally, the parameters: $\mathrm{BOD}_{5}, \mathrm{COD}$, turbidity, color, and conductivity of the treatment inoculated with L. plantarum, R. palustris, S. albus, and A. oryzae were lower compared to the values of the treatment without EM inoculated; that demonstrates the microbiological action in the purification of leachates.

\section{Bibliographic references}

1. Cruz N. Aprovechamiento y manejo de desechos organicos de cocina utilizando Microorganismos Eficientes de Montana MEM aislados de dos bosques secundarios de Costa Rica. Cartago: Instituto Tecnologico de Costa Rica; 2010.

2. Instituto Nacional de Estadistica y Censos. Estadistica de información ambiental economica en gobiernos autonomos descentralizados municipales 2014. Quito: INEC; 2014.

3. Agencia Pública de Noticias del Ecuador y Sudamérica. Cerca del $50 \%$ de residuos sólidos que se produce en Ecuador proviene de Quito y Guayaquil [audio]. Quito: ANDES; 2015.

4. Cadena N. Plan de desarrollo y ordenamiento territorial 20152019. Riobamba: Consejo Cantonal; 2015.

5. Fernandez A. Contaminacion por malos olores: un problema en aumento. Consumer [Internet]. Bizkaia: Fundacion Eroski; [updated 2014 Jan 02; cited 2019 Dec 22]. Available from: https:// www.consumer.es/medio-ambiente.

6. Enciclopedia Ambiental Ambientum. Tratamiento de olores procedentes de la fermentacion. Ambientum [Internet]. Madrid; [updated 2015; cited 2019]. Available from: https://www.ambientum.com/enciclopedia_medioambiental/suelos/

7. Bernache G. Cuando la basura nos alcance: el impacto de la degradación ambiental. Mexico: CIESAS; 2006.

8. Higa T, Parr J. Beneficial and effective microorganisms for a sustainable agriculture and environment. Atami: International Nature Farming Research Center; 1994.

9. Suarez F, Vargas M, Lopez M, Capel C, Moreno J. Antagonistic activity of bacteria and fungi from horticultural compost against Fusarium oxysporum f. sp. melonis. Crop Protection. 2007. 26: 46-53.

10. Huang R, Zong F. Screening of several efficient microbial combinations for deodorization. Hubei Agricultural Sciences. 2011.14.

11. Sanz S. Practicas de microbiologia. 2nd ed. Logroño: Universidad de La Rioja; 2011. 
12. Lopez L, Hernandez M, Colin C, Ortega S, Ceron G, Franco R. Las tinciones basicas en el laboratorio de microbiologia. Mexico: Medigraphic; 2014. p. 10-18.

13. Madigan HT, Martinko JM, Dunalp PV, Clark DP. Biologia de los microorganismos. 12th ed. Madrid: Pearson Education; 2009.

14. Ministerio de Ambiente y Desarrollo Sostenible Republica de Colombia. Protocolo para el monitoreo, control y vigilancia de olores ofensivos. Bogota: MinAmbiente; 2014.

15. Alvarez RJ. Instructivo de uso del multiparametrico WTW, modelo MULTI 340i y medición de muestras. Huaraz: Unasam; 2014.

16. Ingelab. Manual de instrucciones DBO logic. Buenos Aires: Ingelab; [date unknown].

17. Garay J, Betancourt J, Ramirez G, Marin B, Cadavid B, Panizzo L, Lesmes L, Sanchez J, Lozano H, Franco A. Manual de tecnicas analiticas para la determinacion de parametros fisicoquimicos y contaminantes marinos: aguas, sedimentos y organismos. Serie de documentos generales 13. Santa Marta: Invemar; 2003

18. Carpio T. Turbiedad por nefelometría: método B. Bogota: Instituto de Hidrologia, Meteorologia y Estudios Ambientales; 2007.

19. Aguilar M. Water analisis - Determination of color platinum cobalt in natural, wastewaters and wastewaters treated: test method NMX-AA-045-SCFI-2001. Mexico city: Diario oficial de la Federacion; 2001.

20. Nanda S, Sarangi PK, Abraham J. Microbial biofiltration technology for odour abatement: an introductory review. Journal of Soil Science and Environmental Management. 2012. 3(2): 28-35.

21. Wysocka I, Gebicki J, Namiesnik J. Technologies for deodorization of malodorous gases. Environmental Science and Pollution Research. 2019. 26(10): 9409-34.

22. Rybarczyk P, Szulczynski B, Gebicki J, Hupka J. Treatment of malodorous air in biotrickling filters: a review. Biochemical Engineering Journal. 2019. 141: 146-162.
23. Fan YV, Lee CT, Klemes JJ, Chua LS, Sarmidi MR, Leow CW. Evaluation of Effective Microorganisms on home scale organic waste composting. Journal of Environmental Management. 2018. 216: 41-48.

24. Namasivayam KR, Kirithiga R. Effect of formulation of Effective Microorganism EM on post treatment persistence, microbial density and soil macronutrients. Recent Research in Science and Technology. 2010. 2(5): 102-6.

25. Song C, Zhang Y, Xia X, Qi H, Li M, Pan H, Xi B. Effect of inoculation with a microbial consortium that degrades organic acids on the composting efficiency of food waste. Microbial Biotechnology. 2018. 11(6): 1124-36.

26. Jusoh ML, Manaf LA, Latiff PA. Composting of rice straw with Effective Microorganisms EM and its influence on compost quality. Iranian Journal of Environmental Health Science Engineering. 2013. 10: 17 .

27. Miller FC, Macauley BJ, Harper ER. Investigation of various gases, $\mathrm{pH}$ and redox potential in mushroom composting phase I stacks. Australian Journal of Experimental Agriculture. 1991. 31(3): 415-23.

28. Roy D, Azais A, Benkaraache S, Drogui P, Tyagi RD. Composting leachate: characterization, treatment, and future perspectives. Reviews in Environmental Science and Bio/Technology. 2018. 17(2): 323-49.

Received: 13 January 2020

Accepted: 30 January 2020 